\title{
RESPON PETANI TERHADAP EFEKTIVITAS PEMBERIAN POC URINE SAPI PADA PERTUMBUHAN DAN PRODUKSI TANAMAN PAKCOY (Brassica rapa L.)
}

\section{The Farmers' Responses to Effectiveness of the Application of Liquid Organic Fertilizer (Poc) ff Cow Urine on the Growth and Production of Pakchoy Plant (Brassica rapa L.)}

\author{
Andi Muchtar Sudirman', Abdul Rahman Arinong ${ }^{2}$, dan Ramli ${ }^{2}$ \\ ${ }^{1)}$ Program Studi Penyuluhan Pertanian,Politeknik Pembangunan Pertanian Gowa \\ 2) Jurusan Pertanian, Politeknik Pembangunan Pertanian Gowa \\ e-mail: ramlisp8@gmail.com
}

Received: 24 Januari 2020; Accepted: 29 Maret 2020; Published: 30 Juni 2020

\begin{abstract}
ABSTRAK
Penelitian ini bertujuan untuk mengetahui respon petani terhadap efektifitas pemberian POC urine sapi pada pertumbuhan dan produksi tanaman pakcoy. Penelitian dilaksanakan di lahan BPP Bulu Ballea, Desa Kanreapia Kecamatan Tombolo Pao Kabupaten Gowa pada bulan April sampai Juni 2019. Kajian dilakukan dengan menggunakan Rancangan Acak Kelompok dengan 4 perlakuan, yaitu P0 : Tanpa Perlakuan POC urin sapi, P1 : Pemberian POC urin sapi dosis $100 \mathrm{ml}$ per liter air ,P2 : Pemberian POC urin sapi dosis 200 $\mathrm{ml}$ per liter, P3 : Pemberian POC urin sapi dosis $300 \mathrm{ml}$ per liter air, dan 3 kali ulangan sehingga terdapat 12 plot perlakuan. Parameter pengamatan meliputi tinggi tanaman, jumlah daun dan berat basah pakcoy. Pemberian POC urin sapi pada pertumbuhan dan produksi tanaman pakcoy dengan perlakuan P3 (POC urine sapi dosis $300 \mathrm{ml} /$ liter air) memberikan hasil terbaik pada tinggi tanaman yaitu $21,19 \mathrm{~cm}$ dan berat basah yaitu 111,80 gram dan jumlah daun 11,00 helai.
\end{abstract}

Kata Kunci : POC, urine sapi, tanaman pakcoy

\section{ABSTRACT}

The aims of the study was to find out the farmers' responses to effectiveness of the application of liquid organic fertilizer (POC) of cow urine on the growth and production of Pakchoy plant (Brassica rapa L.). The study was conducted at the Area of BPP Bulu Ballea, Kanreapia Village, Tombolo Pao District, Gowa Regency from April-June 2019. The study applied Group Random Design (RAK) consisted of 4 treatments, namely: PO (no treatment/control), P1 (100ml of POC of cow urine/liter of water, P2 (200 ml of POC of cow urine/liter of water), and $P 3(300 \mathrm{ml}$ of POC of cow urine/liter of water). The experiments were repeated for 3 times, therefore there were 12 treatment plots in the study. The parameters were plant height, number of leaves, and wet (gross) weight of Pakchoy plant. The result of the study showed that the application of cow urine as liquid organic fertilizer (POC) in P3 (300 ml/liter of water) gave the best result on the plant height $(21.19 \mathrm{~cm})$, wet (gross) weight (111.80 gram), and the number of leaves (11.00 sheets) of Pakchoy.

\section{Keywords: Liquid organic fertilizer (POC), cow urine, Pakchoy plant}

\section{PENDAHULUAN}

Indonesia adalah Negara agraris yang kebanyakan masyarakat yang bermata pencaharian sebagai petani. Permasalahan petani di Indonesia yaitu terjadinya kerusakan lahan yang disebabkan penggunaan pupuk kimia (anorganik) yang berlebihan sehingga tanah menjadi asam, banyak unsur hara yang terikat dan tidak bisa dimosolir ke tanaman. Kondisi demikian akan berakibat produktivitas tanaman 
menjadi rendah karena kehilangan unsur hara dan bahan organik. Pupuk organik dapat digunakan untuk memperbaiki kerusakan tanah yang di akibatkan oleh penggunaan pupuk anorganik yang berlebihan.

Penggunaan pupuk anorganik untuk meningkatkan produktivitas tanaman dapat ditekan dengan beralih menggunakan pupuk organik. Limbah cair pada peternakan sapi yang berupa urine kurang dimanfaatkan, sehingga dapat mencemari lingkungan. Setiap harinya satu ekor sapi mampu menghasilkan kurang lebih 5 liter urine. Urine sapi yang melimpah berpotensi untuk dijadikan sebagai pupuk organik berupa pupuk organik cair. Pupuk organik cair (POC) yang mengandung unsur yang lengkap yaitu Nitrogen, Fosfor dan Kalium dalam jumlah yang sedikit serta Seng, Besi, Mangan dan Tembaga. Biourine dapat memberikan peningkatan hasil tanaman yang hampir menyamai bahan penyubur tanaman (BPT) (Perdana, 2015).

Penggunaan urine sapi sebagai pupuk organik akan memberikan keuntungan diantaranya harga relatif murah, mudah didapat dan diaplikasikan, serta memiliki kandungan hara yang dibutuhkan tanaman. Pupuk urine sapi mengandung hormon tertentu yang dapat merangsang perkembangan tanaman dan mengandung lebih banyak Nitrogen dan Kalium dibandingkan dengan pupuk kandang sapi padat (Aisyah et al., 2011). Urine sapi dapat dimanfaatkan sebagai pupuk organik cair dengan cara menginkubasinya terlebih dahulu hingga terdekomposisi.

Pada proses dekomposisi urine sapi ditambahkan lengkuas, kencur, kunyit, temulawak dan jahe. Bau urine sapi diharapkan dapat dinetralisir dengan minyak atsiri yang terkandung dalam empon-empon (Tandi et al., 2015). Minyak atsiri tersusun atas eugenol (Kartika et al., 2016), yang berfungsi sebagai antimikroba (Nurawaliyah, 2014), sehingga mikroba anaerob dalam proses pengomposan dapat berkurang. Pupuk POC urine sapi cocok untuk tanaman sayur-sayuran bilah dilakukan pengelolaan yang baik permentasi karena dapat meningkatkan hasil produksi tanaman, salah satunya adalah tanaman pakcoy.

Tanaman pakcoy (Brassica rapa L.) termasuk dalam jenis sayur sawi yang mudah diperoleh dan cukup ekonomis. Saat ini pakcoy dimanfaatkan oleh masyarakat dalam berbagai masakan. Hal ini cukup meningkatkan kebutuhan masyarakat akan tanaman pakcoy. Tanaman pakcoy cukup mudah untuk dibudidayakan. Perawatannya juga tidak terlalu sulit dibandingkan dengan budidaya tanaman yang lainnya. Budidaya tanaman pakcoy dapat dilakukan sendiri oleh masyarakat dengan menggunakan media tanam dalam polibag. Media tanam dapat dibuat dari campuran tanah dan kompos dari sisa limbah (Prasasti 2014).

Berdasarkan data Badan Statistik (2014) produksi sayuran pakcoy di Indonesia dari tahun 2010 sampai 2013 berturut-turut sebesar 583.777 ton,580.968 ton, 594.934 ton dan 600.961 ton. Data tersebut menunjukkan bahwa pada tahun 2011 sampai mengalami penurunan hasil produksi tanaman pakcoy. Salah satu rendahnya tingkat produktifitas tanaman ini adalah masih sedikitnya ketersedian varietas unggul yang tahan terhadap penyakit berbahaya seperti busuk lunak dan bercak daun, serta masih sedikit varietas yang tahan terhadap suhu panas (Rukmana, 1994). Selain itu, beralihnya fungsi lahan pertanian menjadi daerah perindustrian menyebabkan semakin sempitnya lahan pertanian yang potensial untuk bercocok tanam. Oleh karena itu, diperlukan adanya suatu sistem bercocok tanam yang dapat menggunakan lahan sempit tanpa mengurangi tingkat produktivitas pertanian serta menghasilkan kualitas produksi yang lebih tinggi. Berdasarkan bahasan tersebut, peneliti mencoba melakukan kaji widya tentang respon petani terhadap efektivitas pemberian POC urine sapi pada pertumbuhan dan produksi tanaman pakcoy.

\section{METODE PENELITIAN}

\section{Tempat dan Waktu}

Penelitian ini dilaksanakan di Desa Kanrapia, Kecamatan Tinggi Moncong, Kabupaten Gowa berlangsung pada bulan Maret sampai bulan Mei 2019.

\section{Alat dan Bahan}

Adapun alat dan bahan yang digunakan dalam pelaksanaan kaji widya terdiri dari : Alat yang digunakan adalah : Tong plastik kapasitas 50 liter, talang plastik untuk pesemaian benih, ember, cangkul, parang, sekop, gelas ukur, meteran, $\mathrm{pH}$ tester, timbangan, sprayer, selang plastik, saringan, jerken, kamera dan perangkat lektop. Bahan yang digunakan adalah : benih tanaman pakcoy (TakII see), urine sapi 20 liter, 
EM4 1 liter, gula merah $1 \mathrm{Kg}$, kunyit, Jahe, serai, ATK.

\section{Metode Pelaksanaan}

Penelitian ini dilaksanakan dengan menggunakan Rancangan Acak Kelompok (RAK) yang terdiri atas 4 perlakuan dan 3 ulangan, sehingga terdapat 12 plot percobaan, dengan luas bedengan $100 \mathrm{~cm}$ x $130 \mathrm{~cm}$, jarak antara bedengan $40 \mathrm{~cm}$, jarak antara tanaman 20 $\mathrm{cm} \times 25 \mathrm{~cm}$, sehingga total populasi pada 12 plot 288 tanaman. Perlakuannya adalah sebagai berikut:

P0 : 0 Tanpa Perlakuan (Kontrol)

P1 : Pemberian POC urine sapi dosis $100 \mathrm{ml}$ per liter air

P2 : Pemberian POC urine sapi dosis $200 \mathrm{ml}$ per liter air

P3 : Pemberian POC urine sapi dosis $300 \mathrm{ml}$ per liter air

Sampel yang diambil adalah 5 tanaman setiap plot sehingga terdapat 60 sampel untuk semua plot percobaan, penentuan sampel sistem sampling yaitu sampel yang ditentukan oleh penulis sesuai dengan beberapa faktor yang telah dipertimbangkan.

\section{Parameter} adalah:

Parameter pengamatan pada penelitian ini

1. Tinggi tanaman $(\mathrm{cm})$

Tinggi tanaman diukur mulai dari pangkal batang sampai daun yang tertinggi setelah diluruskan. Pengukuran dilakukan sebanyak 3 kali dimulai pada saat tanaman berumur 2 (dua), 3 (tiga) dan 4 (empat) minggu setelah tanaman dipindahkan ke bedengan dengan interval waktu pengukuran satu minggu sekali.

2. Jumlah daun (helai)

Pengamatan atau penghitungan jumlah daun dilakukan pada daun yang telah membuka sempurna. Pengamatan dilakukan pada saat tanaman berumur 2 (dua), 3 (tiga) dan 4 (empat) minggu setelah tanaman dipindahkan ke bedengan dengan interval waktu pengamatan satu minggu sekali.

3. Berat segar (Basah)

Kegiatan ini untuk mengetahui berat basah (segar) dari tanaman pakcoy pada setiap perlakuan masing- masing bedengan setelah proses pemanenan dilakukan pada umur tanaman 40 hari setelah tanam atau sekitar 2 bulan setelah semai.

\section{HASIL DAN PEMBAHASAN}

Hasil

Hasil kajian pemberian POC urine sapi pada pertumbuhan dan produksi tanaman pakcoy dengan parameter yang ukuran yaitu tinggi tanaman, jumlah daun dan berat basah yang dilakukan dari umur 2, 3 dan 4 minggu setelah tanam, dapat dilihat pada uraian berikut :

\section{Tinggi Tanaman}

Hasil pengamatan tinggi tanaman pakcoy terhadap pemberian POC urine pada umur 2, 3 dan 4 minggu setelah tanam dapat dilihat pada table 1. Tabel 1 Menunjukkan bahwa rata-rata tinggi tanaman pakcoy yang diamati mengalami peningkatan pada pada umur 2, 3 dan 4 minggu setelah tanam. Umur 2 minggu setelah tanam P0,P1,P2 dan P3 tidak berbeda nyata.

Tabel 1. Rata - rata Tinggi Tanaman Pakcoy Umur 2, 3 dan 4 Minggu Setelah Tanam (MST)

\begin{tabular}{cccc}
\hline \multirow{2}{*}{ Perlakuan } & \multicolumn{3}{c}{ Tinggi Tanaman Pakcoy } \\
\cline { 2 - 4 } & 2 & 3 & 4 \\
\hline PO & $11.33 \mathrm{a}$ & $12.16 \mathrm{a}$ & $14.47 \mathrm{a}$ \\
P1 & $14.29 \mathrm{a}$ & $16.75 \mathrm{~b}$ & $18.53 \mathrm{~b}$ \\
P2 & $13.29 \mathrm{a}$ & $16.23 \mathrm{~b}$ & $17.99 \mathrm{~b}$ \\
P3 & $15.48 \mathrm{a}$ & $18.70 \mathrm{c}$ & $21.19 \mathrm{c}$ \\
\hline BNT0,05 & 2.00 & 1.72 & 2.12 \\
KK\% & 7.37 & 5.39 & 5.89 \\
\hline
\end{tabular}

Keterangan: Angka-angka pada kolom yang sama diiukuti oleh huruf yang sama berarti tidak berbeda nyata pada taraf uji BNT 0,05 
Umur 3 minggu setelah tanam P2 tidak berbeda nyata dengan P1 dan P3, tetapi berbeda nyata dengan $\mathrm{P} 0$. Umur 3 minggu setelah tanam P2 tidak berbeda nyata dengan P1 dan P3, tetapi berbeda nyata $\mathrm{P} 0$. Hasil sidik ragam dan uji BNT 0,05 pada umur tanaman 2,3 dan 4 minggu setelah tanam. Berdasarkan Gambar 1 Perlakuan pemberian POC urine sapi, P0 Tampa perlakuan / kontrol menunjukkan tinggi tanaman terendah yaitu $14,17 \mathrm{~cm}$, sedangkan tertinggi terdapat pada P3 POC Urine sapi dosis $300 \mathrm{ml}$ per liter air yaitu $21,19 \mathrm{~cm}$ pada umur 4 minggu setelah tanam.

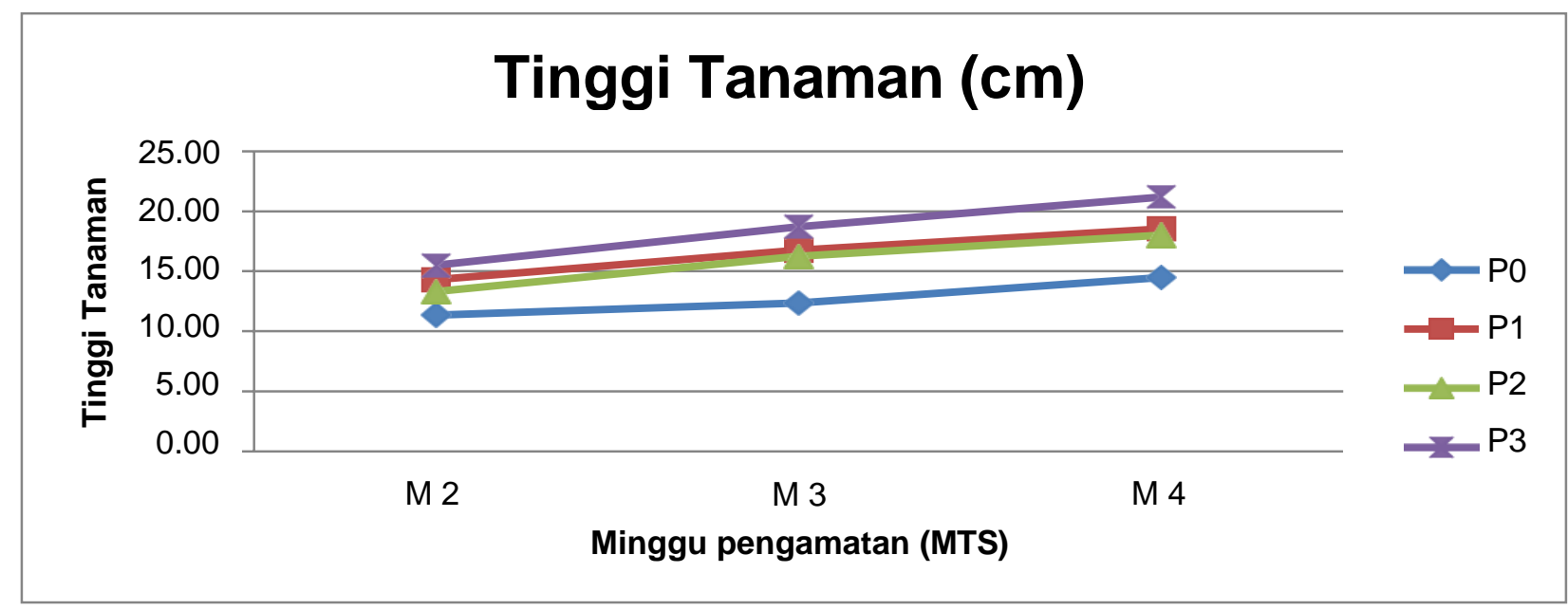

Gambar 1 . Tinggi Tanaman Pakcoy Umur 2, 3 dan 4 MST.

\section{Jumlah Daun}

Hasil pengamatan jumlah daun tanaman pakcoy terhadap pemberian POC urine sapi pada umur 2, 3 dan 4 minggu setelah tanam Tabel 2 menunjukkan rata- rata jumlah daun pakcoy yang diamati mengalami perkembangan pada umur 2, 3 dan 4 minggu setelah tanam. Umur 2 minggu setelah tanam P0,P1, P2 dan P3 tidak berbeda nyata .Umur 3 minggu setelah tanam P0 tidak berbeda nyata dengan P1 dan P2, tetapi berbeda nyata dengan P3. Umur 4 minggu setelah tanam $\mathrm{P} 0$ tidak berbeda nyata dengan $\mathrm{P} 1$ dan P2, tetapi berbeda nyata dengan P3. Hasil analisis sidik ragam dan uji BNT 0,05.

Berdasarkan Gambar 2 perkembangan jumlah daun tanaman pakcoy pada umur 2, 3 dan 4 minggu setelah tanam. pada pemberian POC urine sapi. Perkembangan jumlah daun terbaik diperoleh dari perlakuan P3 POC urine sapi dosis $300 \mathrm{ml}$ per liter air yaitu mencapai 11,00 helai daun dibandingkan dengan $\mathrm{P} 0, \mathrm{P} 1$ dan $\mathrm{P} 2,4$ minggu setelah tanam.

Tabel 2. Rata - rata Jumlah Daun Tanaman Pakcoy Umur 2, 3 dan 4 Minggu Setelah Tanam (MST)

\begin{tabular}{cccc}
\hline \multirow{2}{*}{ Perlakuan } & \multicolumn{3}{c}{ Jumlah daun Tanaman Pakcoy } \\
\cline { 2 - 4 } & 2 & 3 & 4 \\
\hline P0 & $5.53 \mathrm{a}$ & $6.40 \mathrm{a}$ & $8.20 \mathrm{a}$ \\
P1 & $5.67 \mathrm{a}$ & $6.90 \mathrm{a}$ & $8.47 \mathrm{a}$ \\
P2 & $5.47 \mathrm{a}$ & $7.73 \mathrm{a}$ & $9.20 \mathrm{a}$ \\
P3 & $7.40 \mathrm{a}$ & $9.60 \mathrm{~b}$ & $11.00 \mathrm{~b}$ \\
\hline BNT0.05 & 1.09 & 1.06 & 1.58 \\
KK\% & 8.72 & 10.97 & 8.58
\end{tabular}

Keterangan: angkah-angkah pada kolom yang sama, diikuti dengan huruf yang sama berarti tidak berbeda nyata pada taraf uji BNT 0,05 


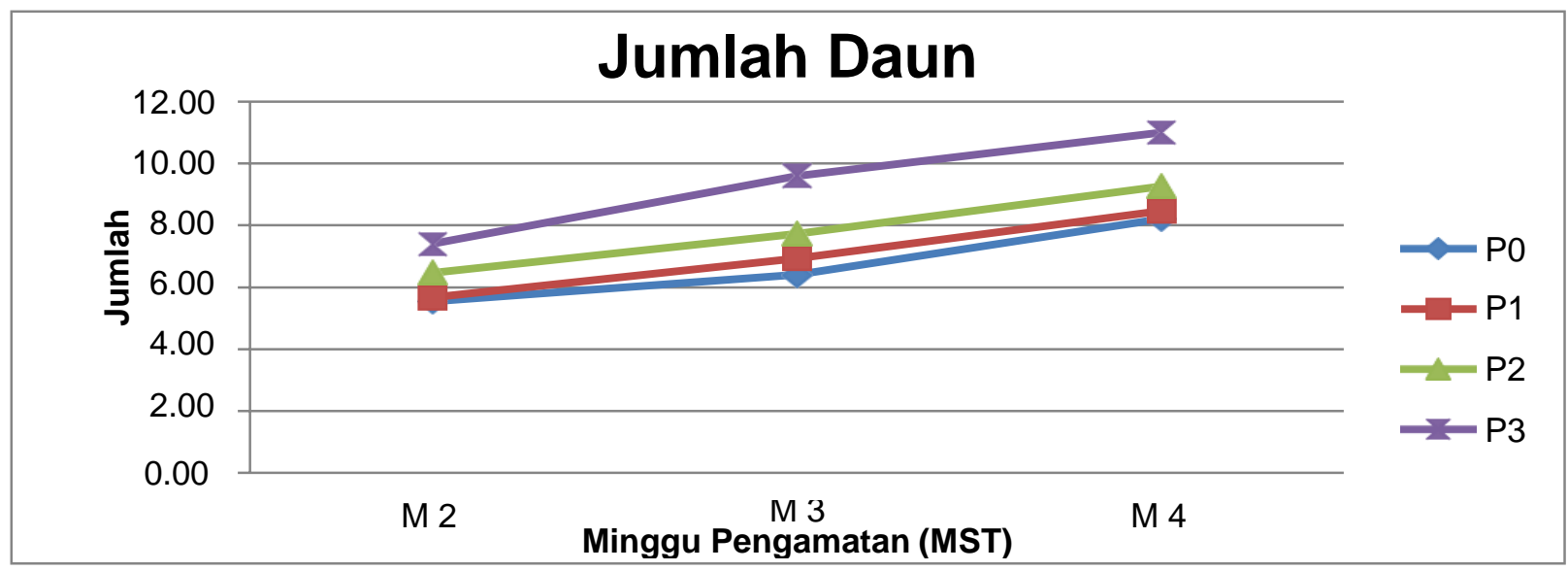

Gambar 2. Jumlah Daun Tanaman Pakcoy Umur 2, 3 dan 4 MST

\section{Berat Basah}

Hasil perhitungan berat basah tanaman pakcoy terhadap pemberian POC urine sapi perlakuan pada umur 4 minggu setelah tanam. Tabel 3 menunjukkan rata- rata berat basah tanaman pakcoy umur 4 minggu setelah tanam. P3 sangat berbeda nyata dengan P0 dan berbeda nyata dengan P1 dan P2. Untuk lebih jelasnya dapat dilihat pada Gambar 3. Sedangkan hasil analisis sidik ragam berat umur 4 minggu sesudah tanam. Berdasarkan Gambar 3 menunjukkan berat basah tanaman pakcoy pada umur 4 minggu setelah tanam. Perkembangan berat yang tertinggi terdapat pada P3 POC Urine sapi dosis $300 \mathrm{ml}$ per liter air yaitu 111.80 gram, sedangakan yang terendah P0 Tampa perlakuan / kontrol yaitu 42,27 gram.

Tabel 3. Rata - rata Berat Tanaman Pakcoy Pada Umur 4 Minggu Setelah Tanam (MST)

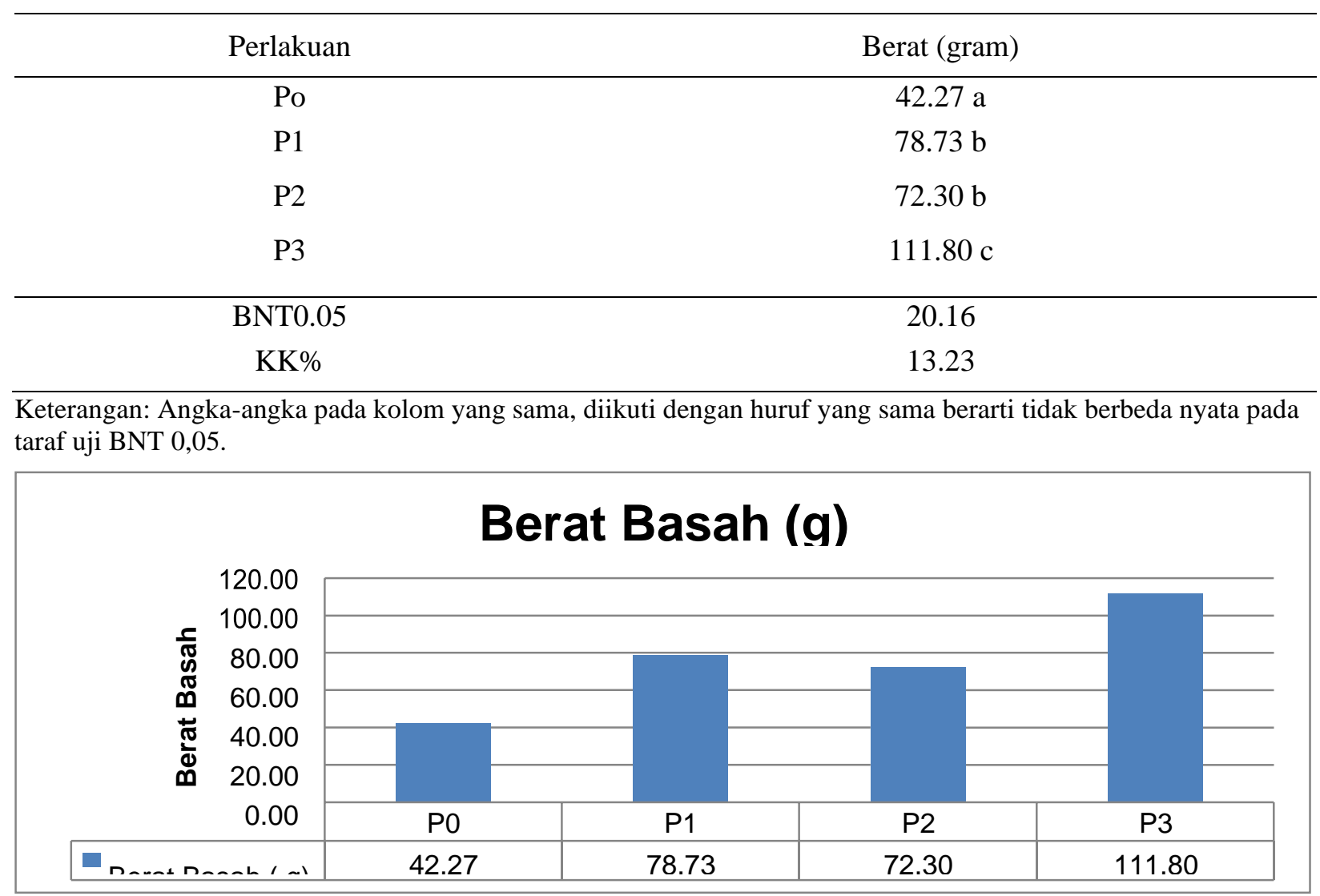

Gambar 3. Berat Basah Tanaman Pakcoy Umur Panen 4 MST 


\section{PEMBAHASAN}

\section{Tinggi Tanaman}

Hasil analisis sidik ragam pada Tabel 1 dan Gambar 1 terhadap rata- rata tinggi tanaman pakcoy umur 2, 3 dan 4 minggu setelah tanam menunjukkan peningkatan. Hasil tinggi tanaman terbaik sampai dengan umur 4 minggu setelah tanam diperoleh pada perlakuan P3 POC urine sapi dosis $300 \mathrm{ml}$ per liter air yaitu $21,19 \mathrm{~cm}$, dibandingkan dengan perlakuan P0 tampa perlakuan / kontrol hanya mencapai $11,47 \mathrm{~cm}$.

Perlakuan P1 POC urine sapi dosis $100 \mathrm{ml}$ per liter air hanya mencapai $18,53 \mathrm{~cm}$, sedangkan perlakuan P2 POC urine sapi dosis $200 \mathrm{ml}$ per liter air hanya mencapai $17,99 \mathrm{~cm}$. Hal ini disebabkan kandungan larutan POC urine sapi mengandung zat hara terutama kandungan $\mathrm{N} \mathrm{1,4}$ hingga $2,2 \%$, fosfor 0,6 hingga $0,7 \%$ dan kalium 1,6 hingga 2,1 \% yang merupakan penyusun utama protein sehingga mampu menyediakan unsur hara yang terkait dengan pertumbuhan tinggi tanaman (Murniyati dan Safriani, 2013).

Peningkatan $\mathrm{N}$ dalam suatu larutan menyebabkan meningkatnya jumlah $\mathrm{N}$ yang diserap oleh tanaman, sehingga jaringan merismatik pada titik tumbuh batang semakin aktif, ruas batang akan terbentuk, tanaman bertambah panjang dan tanaman bertumbuh semakin tinggi. Umur 14 dan 21 hari setelah tanam, unsur hara yang diserap oleh tanaman semakin meningkat sementara persediaan hara yang mendukung perkembangan vegetatif semakin berkurang. maka semakin bertambahnya umur pertumbuhan tanaman, semakin diperlukan pula pemberian unsur hara untuk pertumbuhan dan perkembangan pada tanaman pakcoy.

\section{Jumlah Daun}

Hasil analisis sidik ragam dan Gambar 2 menunjukkan perkembangan jumlah daun tanaman pakcoy umur 2, 3 sampai 4 minggu setelah tanam. Perlakuan P3 POC urine sapi dosis $300 \mathrm{ml}$ per liter air memberikan hasil terbaik yaitu 11.00 helai daun, dibanding dengan perlakuan P0 tampa perlakuan / kontrol hanya mencapai 8,20 helai daun. Perlakuan P1 POC urine sapi dosis $100 \mathrm{ml}$ per liter air hanya mencapai 8,47 helai daun, sedangkan pelakuan P2 POC urine sapi dosis $200 \mathrm{ml}$ per liter air hanya mencapai 9,20 helai daun. Hal ini disebabkan hara yang terkandung pada POC urine sapi mampu menyediakan unsur esensial bagi pertumbuhan tanaman terutama unsur $\mathrm{N}$. Pemberian pupuk dengan kadar Nitrogen yang tinggi dapat mempercepat pertumbuhan dan perkembangan organ tanaman sehingga lebih cepat mengalami pertambahan jumlah daun dan ukuran luas daun (Nasaruddin dan Rosmawati, 2010).

Ketersediaan unsur hara yang cukup untuk pertumbuhan dan perkembangan tanaman akan mendukung laju fotosintesis yang cepat, dengan fotosintesis yang sempurna, maka pada proses pembentukan karbohidrat, lemak dan protein dapat berjalan dengan sempurna pula, sehingga akan diperoleh hasil yang maksimal. Dosis yang diberikan menunjukkan perkembangan pertumbuhan jumlah daun yang terbaik adalah POC urine sapi $300 \mathrm{ml}$ per liter air. Hal ini sejalan dengan hasil penelitian Nathania (2012) menunjukkan pemberian urinee sapi dengan kosentrasi $300 \mathrm{ml}$ per liter air mampu meningkatkan jumlah daun hingga 9 helai. Peningkatan daun disebabkan, urine sapi mengandung beberapa unsur yang diperlukan oleh tanaman untuk proses pertumbuhan seperti, Nitrogen, Fosfot, Kalium, Carbon, Air, dan fitohormon auksin, sehingga dapat meningkatkan jumlah daun tanaman pakcoy (Oka, 2014).

\section{Berat Basah Segar}

Hasil sidik ragam pada Tabel 3 dan Gambar 3 terhadap rata-rata jumlah produksi tanaman pakcoy tertinggi umur 4 minggu setelah tanam terdapat pada P3 POC urine sapi dosis 300 $\mathrm{ml}$ per liter air hanya mencapai 111,80 gram, dibandingkan dengan perlakuan P0 tampa perlakuan/ kontrol mencapai 42,27 gram. Perlakuan P1 POC urine sapi dosis $100 \mathrm{ml}$ per liter air hanya mencapai 78,73 gram, sedangkan perlakuan P2 POC urine sapi dosis $200 \mathrm{ml}$ per liter air hanya mecapai 72,30 gram. Hal ini disebabkan konstribusi hara dan penyinaran untuk proses fotosintetis yang dapat merangsang dan mempercepat pertumbuhan fisik tanaman sehingga tanaman memberikan hasil yang lebih besar terhadap produksi tanaman.

Unsur hara Nitrogen berperan penting dalam pertumbuhan generative tanaman. Nitrogen yang terdapat dalam pupuk organik tersedia secara perlahan lahan bagi tanaman .Dan pemberian unsur Nitrogen dan Fospor yang cukup dapat membantu dan mengubah karbohidrat yang dihasilkan dalam proses 
fotosintesis menjadi protein sehingga akan membantu menamba lebar, panjang, dan jumlah daun oleh Sukmawati (2012).

\section{KESIMPULAN}

Pemberian POC urine sapi terhadap pertumbuhan dan produksi tanaman pakcoy dengan perlakuan (POC urine sapi dosis $300 \mathrm{ml}$ per liter air) memberikan hasil terbaik pada tinggi tanaman yaitu $21,19 \mathrm{~cm}$ dan berat basah yaitu 111,80 gram dan jumlah daun 11,1 helai dibanding perlakuan yang lain.

\section{DAFTAR PUSTAKA}

Aisyah, S., N. Sunarlim, B. Solfan. 2011. Pengaruh urinee sapi terfermentasi dengan dosis dan interval pemberian yang berbeda terhadap pertumbuhan tanaman sawi (Brassica juncea L.). Jurnal Agroteknologi. 2(1): 1-5.Fakultas Pertanian dan Uin Suka Riau.Riau

Kartika, J.G., K. Suketi, N. Mayasari. 2016. Produksi biomassa dan minyak atsiri kemangi (Ocimum

basilicum L.) pada berbagai dosis pupuk nitrogen dan pupuk cair hayati. J. Hort. Indonesia. 7(1): 56-62.Depertemen Agronomi dan Hortikultura. IPB.Bogor

Murniati, N., \& Safriani, E. 2013. Pemanfaatan Urine Sapi Sebagai Pupuk Organik Cair Untuk Meningkatkan Produktivitas

Tanaman Selada ( Lactuca sativa L.). Jurnal Silampari Fakultas Pertanian UNMURA, 1 (2): 9-17 Pangan dan Gizi, Fatameta. IPB, Bogor

Nathania, B., I.M Sukewijaya, N.W.S. Sutari. 2012. Pengaruh aplikasi biourine gajah terhadap pertumbuhan dan hasil tanaman saw hijau ( Brassica juncea L.). E- Jurnal Agroekoteknologi Tropika. 1 (1): $72-$ 28.Pogram istudi Agroteknologi Fakultas Pertanian,Unifersitas Udaya. Bali

Nazaruddin dan Rosmawati. 2010. Pengaruh
Pupuk Organik Cair Hasil Fermentasi Daun Gamal, Batang Pisang dan Sabut Kelapa Terhadap Pertumbuhan Bibit Kakao. Fakultas Pertanian, Universitas Hasanuddin.Makassar

Nurawaliah, S. 2014. Pemanfaatan ampas penyulingan daun nilam sebagai bahan litter pada pemeliharaan ayam broiler. Prosiding Seminar Nasional "Inovasi Teknologi Pertanian Spesifik Lokasi", Banjarbaru 6-7 Agustus2014: 587

Oka, D.N 2014. Urine sapi meningkatkan produksi tanaman sawi hijau (Brassica junecea L.) dan inplementasinya pada pembelajaran hortikultura. Suluh Pendidikan, 12(2): 113-122

Perdana, S.N., W.S. Dwi, M. Santoso. 2015. Pengaruh aplikasi biourine dan pupuk terhadap pertumbuhan dan hasil tanaman bawang merah (Allium ascalonicum L.). J. Prod. Tan. 3(6): 457-463.Universitas Brawijaya. Malang

Prasasti, D. 2014. Perbaikan kesuburan Tanah Liat Dan Pasir Dengan Penambahan Kompos Limbah Sagu Untuk Pertumbuhan Dan Produksi Tanaman Pakcoy (Brassica Rapa Var Chenensis). Universitas Diponegoro. Semarang.

Rukmana, Rahmad.1994 Bayam, Bertanam \& Pengelolaan Pascapanen. ;kanisius Yokyakarta.

Sukmawati 2012 pada jurnal AGRIFOR Volume XVI Nomor 1 maret 2017 (Uji pertumbuhan dan hasil tanaman Pakcoy brassica Rapa. L). Agroteknologi Sekolah Tinggi ilmu Pertanian Kutai Timur. Sanggata

Tandi, O.G., J. Paulus, A. Pinaria. 2015. Pertumbuhan dan produksi bawang merah (Allium ascalonicum L.) berbasis aplikasi biourine sapi. Jurnal Eugenia. 21(3): 142-150. Fakultas Pertanian Ustrat. Manado 